\title{
OCCURRENCE AND Distribution OF MARINE MAMMAL STRANDings in Todos SANTOS Bay, Baja California, Mexico, 1998-2001
}

\author{
Erick Bravo ${ }^{1,2}$, Gisela Heckel ${ }^{2,3}$ *, Yolanda Schramm ${ }^{1,2}$ and Roberto Escobar-Fernández ${ }^{4}$
}

\begin{abstract}
AвSTRACт: The occurrence and geographic distribution of marine mammal strandings along Todos Santos Bay, Baja California, Mexico, were investigated from 1998 to 2001. The study was carried out along 30km of coast, divided into rocky and sandy shores. During the study period we responded to calls from the public about dead stranded marine mammals (SMM), and from March 1999 to December 2001 the coast was also monitored ( $211 \mathrm{~km}$ total effort). A total of 153 SMM (90 from notifications, 63 from beach monitoring) from nine different species were recorded: $76 \%(n=117)$ were California sea lions (Zalophus californianus), the most abundant pinniped on the western coast of the Baja California Peninsula. Adult males stranded more often than other age and sex classes $(\mathrm{P}<0.05)$. The highest frequency of California sea lion strandings was located on sandy beaches $(\mathrm{P}<0.05)$ because carcasses may be deposited and remain more easily there than on rocky beaches. The $1998 \mathrm{El}$ Niño event influenced stranding frequencies; most SMM were recorded during that year. As to seasons of the year, most SMM were recorded during spring; this may indicate a higher abundance of marine mammals in the area during this part of the year. Probable human-induced injuries were observed in $17 \%(n=26)$ of all animals. Most of these were Z. californianus ( $\mathrm{n}=24)$, probably due to their known interaction with fisheries; $70 \%$ were males.
\end{abstract}

Resumen: Se investigó la distribución espacial y temporal de los varamientos de mamíferos marinos en la Bahía de Todos Santos, Baja California, México, de 1998 a 2001. El estudio se realizó a lo largo de 30km de costa, dividida en costa rocosa y arenosa. Durante el periodo del estudio se respondió a llamados de la población sobre mamíferos marinos varados (MMV), y desde marzo de 1999 a diciembre de 2001 se hicieron monitoreos de las playas ( $211 \mathrm{~km}$ de esfuerzo total). Se registraron un total de 153 MMV (90 de avisos, 63 de monitoreos) pertenecientes a nueve especies diferentes: 76\% ( $n=117$ ) fueron lobos marinos de California (Zalophus californianus), el pinnípedo más abundante en la costa occidental de la península de Baja California. Los machos adultos se vararon con más frecuencia que otras clases de edad y sexo $(\mathrm{P}<0.05)$. La mayor frecuencia de los varamientos de lobo marino de California se ubicó en playas arenosas $(\mathrm{P}<0.05)$, probablemente porque los cadáveres se depositan y permanecen más fácilmente ahí que en playas rocosas. El evento de El Niño en 1998 influenció las frecuencias de los varamientos; la mayoría de los MMV se registraron durante ese año. En cuanto a estaciones del año, la mayoría de los MMV se registraron durante la primavera; esto puede indicar una mayor abundancia de mamíferos marinos en el área durante esta temporada del año. Se observaron heridas de probable origen antropogénico en $17 \%(n=26)$ de todos los animales. La mayoría fueron Z. californianus $(\mathrm{n}=24)$, probablemente debido a su conocida interacción con pesquerías; $70 \%$ fueron machos.

KEYwords: Strandings, California sea lion, Zalophus californianus, Baja California, Mexico.

\section{Introduction}

Thirty-three of 44 species of cetaceans and all four species of pinnipeds reported for Mexico occur along the western coast of the Baja California Peninsula (Aurioles, 1993; Carwardine, 2000; Reeves et al., 2002). This region's high diversity is related in part to food availability produced by the southward flowing California Current of cold and temperate waters, and the convergence with warm waters from the northward-flowing North Equatorial Countercurrent (Torres and Zárate, 1991).

Marine mammals die as a result of starvation, predation, trauma, and diseases. By understanding the normal causes and mortality patterns, we may recognize extraordinary events and determine their causes and impacts on the population (Geraci et al., 1999). In addition, it is important to know the species that strand, the seasons and the localities, to warn the human population about possible public health problems, both rural and urban, due to zoonosis (Kennedy-Stoskopf, 2001).

The mortality related to marine mammal strandings may be caused by natural or anthropogenic factors. Marine mammals, due to their high trophic level (Le Boeuf et al., 1983), may indicate the health of the ecosystem in which they live (Skoch, 1990; Lynn et al., 2001). Moreover, data obtained from strandings can convey information about marine mammal distribution, abundance, seasonal movements, biology, life history, health, mortality rates, and the interaction of marine mammals with human activities (Mead, 1979; Woodhouse, 1991; Geraci and Lounsbury, 1993; Wiley et al., 1995; Wilkinson and Worthy, 1999).

In the winter of 1997-1998, a group of volunteers under the non-governmental organization Ensenada Marine

\footnotetext{
${ }^{1}$ Facultad de Ciencias Marinas, Universidad Autónoma de Baja California. Km 103 Carretera Tijuana-Ensenada, 22830 Ensenada, Baja California, Mexico.

${ }^{2}$ Investigación y Conservación de Mamíferos Marinos de Ensenada. A.C., Plácido Mata 2309 Depto. D-5, Condominio Las Fincas, 22810 Ensenada, Baja California, Mexico.

${ }^{3}$ Centro de Investigación Científica y de Educación Superior de Ensenada. Km 107 Carretera Tijuana-Ensenada, 22860 Ensenada, Baja California, Mexico.

${ }^{4}$ Instituto de Investigaciones Oceanológicas, Universidad Autónoma de Baja California. Km 103 Carretera Tijuana-Ensenada, 22830 Ensenada, Baja California, Mexico.

* Corresponding author: gheckel@cicese.mx
} 
Mammal Research and Conservation (ICMME, by its Spanish acronym) started systematically recording data from strandings that occur along Todos Santos Bay, near the port of Ensenada, Baja California, Mexico. In this report we analyzed the occurrence and distribution of dead stranded marine mammals from 1998 to 2001, the differences in the number of strandings according to sex and age groups of the most frequently stranded species (California sea lion, Zalophus californianus), and the rates of animals that died due to human-induced injuries.

\section{Material and Methods}

\section{Study area}

Todos Santos Bay, Baja California, is located on the northwestern coast of the Baja California Peninsula, between $31^{\circ} 40^{\prime} \mathrm{N}$ and $31^{\circ} 56^{\prime} \mathrm{N}$ and $116^{\circ} 36^{\prime} \mathrm{W}$ and $116^{\circ} 50^{\prime} \mathrm{W}$ (Figure 1), $110 \mathrm{~km}$ south of the USA-Mexico border. The port of Ensenada lies in the Bay that is $18 \mathrm{~km}$ long and $14 \mathrm{~km}$ wide on average and relatively shallow, since approximately $75 \%$ of its area is less than $50 \mathrm{~m}$ deep. The remaining $25 \%$ is part of a submarine canyon (400m deep) located between Punta Banda Peninsula and the southern Todos Santos Island (Secretaría de Marina, 1974).

\section{Data collection}

The study was conducted along the coast of Todos Santos Bay, approximately 30km from San Miguel Point in the north to a site known as "Whale's Corner" in the south. For data analysis, the coast was divided into two zones according to the general sedimentary features: rocky shore from San Miguel Point to El Gallo River, and sandy shore from El Gallo River to Whale's Corner (Figure 1).

Since November 1997, ICMME receives notifications (telephone calls) about stranded marine mammals (SMM) from public or private institutions and the general public. ICMME volunteers go to the site, record data, and bury all carcasses in the beach to avoid doublecounting. Data collected from January 1998 to December 2001 were analyzed in this study.

In addition, from March 1999 to December 2001 the study area (from San Miguel Point to Whale's Corner) was monitored $(211 \mathrm{~km}$ total effort) in search of SMM by dividing it into portions of 2 to $4 \mathrm{~km}$. Each portion was surveyed at least once per season of the year. During each monitoring we collected data related to searching effort: date, start and endpoint of monitored beach portion, and length in $\mathrm{km}$. Data about SMM were recorded as in notifications.

During each event we followed a standardized protocol and used data forms based on Geracy and Lounsbury (1993). Data recorded included the geographic location with GPS, species, carcass condition, total length, and sex. The age group was determined based on species and total length, and the sex according to Geraci and Lounsbury (1993). Human-related injuries were determined and included gunshot wounds, cuts in the skin probably caused by propellers (from vessel collisions) or knives, and mutilation of fins and flippers, probably to disentangle carcasses from fishing nets (Hare and Mead, 1987; Read and Murray, 2000).

\section{Data analyses}

Data obtained from notifications may vary in space and time because the public who reports strandings use the area differently. Therefore, data obtained from notifications and beach monitoring were analyzed separately. Possible differences in the frequency of stranded species were tested by means of the goodness-of-fit test $\left(X^{2}\right.$; Neave and Worthington, 1988; Zar, 1996).

All strandings of pinnipeds and cetaceans were plotted on maps of the study area, separated by notifications and monitoring. Further, possible significant differences in stranding rate of California sea lions (stranded sea lions $/ \mathrm{km}$, data from beach monitoring) between rocky and sandy shores (classified according to García and Chee, 1976; Figure 1) were tested. Since the analyzed data did not meet the assumption of normal distribution (Kolmogorov-Smirnov test for normality; Neave and Worthington, 1988) for parametric statistic tests we used the non-parametric Mann-Whitney test for two independent samples (Neave and Worthington, 1988) and applied the corrected $z$ (Sheskin, 2000).

The frequency of stranded animals was compared between years and seasons of the year, separated by notifications and monitoring reports. Seasons were divided according to solstices and equinoxes during the studied years into spring (March 20-June 20), summer (June 21 - September 21), fall (September 22 - December 20), and winter (December 21 - March 19) (U.S. Naval Observatory, 2002). To further analyze data from beach monitoring, we used both frequencies of stranded marine mammals (SMM) and a stranding rate (number of stranded marine mammals per monitored $\mathrm{km}=\mathrm{SMM} / \mathrm{km}$ ) to correct for searching effort.

For the most frequently stranded species (Zalophus californianus) we searched for differences in stranding frequency between males and females $\left(X^{2}\right)$ and age groups, separated by data from notifications and monitoring. Age classes of California sea lions were determined according to length and sex of carcass (King, 1983; Riedman, 1990; Reeves et al., 1992; Heath, 2002): pups, $0.75-1.00 \mathrm{~m}$, juveniles $1.00-1.39 \mathrm{~m}$, adult females $1.40-1.80 \mathrm{~m}$, subadult males $1.40-2.00 \mathrm{~m}$, adult males $>2.00 \mathrm{~m}$. Finally, we calculated the rates of SMM that had human-induced injuries, and we divided them into age and sex classes. 


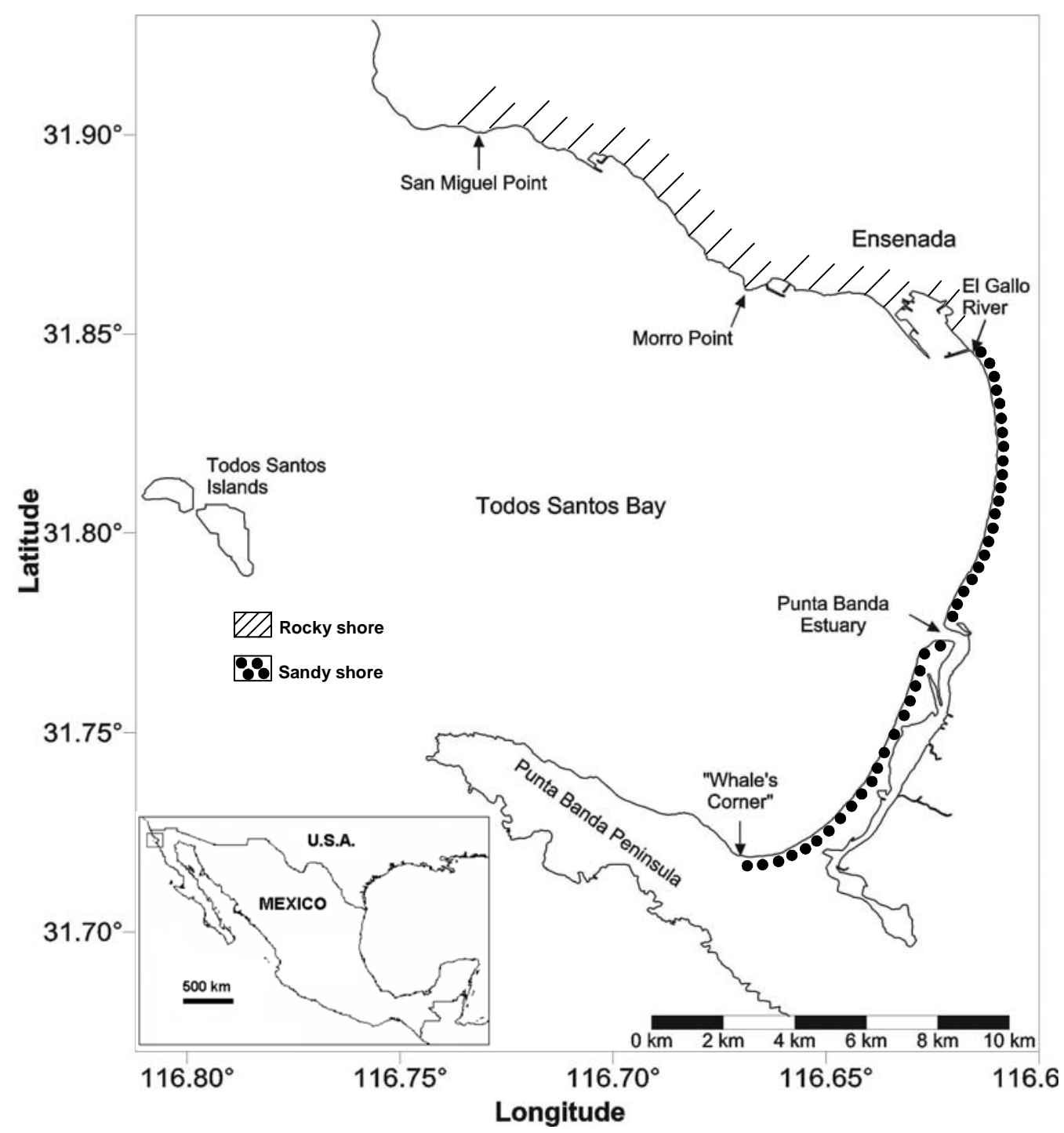

Figure 1. Todos Santos Bay, Baja California, Mexico, study area limits and zones in which it was divided for analyses (rocky shore and sandy shore).

\section{Results}

\section{Stranded species}

From 1998 to 2001, we received notifications about 90 marine mammals that stranded in the study area. In addition, we recorded 63 dead stranded animals during beach monitoring from 1999 to 2001 (Table $1)$. Ninety-nine per cent of all carcasses were decomposed (Codes 3 - fair, and 4 - advanced decomposition, according to Geraci and Lounsbury, 1993; Rowles et al., 2001). Nine different species were recorded: California sea lion (Zalophus californianus), harbor seal (Phoca vitulina richardsi), northern elephant seal (Mirounga angustirostris), short-beaked common dolphin (Delphinus delphis), bottlenose dolphin (Tursiops truncatus), Pacific white-sided dolphin (Lagenorhynchus obliquidens), rough-tooted dolphin (Steno bredanensis), gray whale (Eschrichtius robustus), and blue whale (Balaenoptera musculus) (Table 1). There was a significant difference between their stranding frequencies recorded from notifications $\left(X^{2}=394.400\right.$, $\mathrm{p}<0.001$, d.f. $=8)$ and from beach monitoring $\left(X^{2}=235.794, p<0.001\right.$, d.f.=7). When the dataset excluded California sea lions, there was no significant difference in the stranding frequencies (notifications: $X^{2}=10.619, P>0.05, \mathrm{df}=7$, monitoring: $X^{2}=7.867$, $\mathrm{P}>0.05, \mathrm{df}=6$ ). Relative frequencies showed similar tendencies in both data sets: California sea lions had the highest stranding frequency $(76.7 \%$ from notifications and $76.2 \%$ from beach monitoring), followed by other pinnipeds $(12.2 \%$ and $13.1 \%$, respectively), odontocetes $(7.8 \%$ and $4.8 \%)$, and mysticetes $(3.3 \%$ and $0 \%)$. 
Table 1. Frequencies of stranded marine mammals (SMM) in Todos Santos Bay, Baja California, Mexico, 1998-2001. There was a significant difference between frequencies of stranded species recorded from notifications $\left(X^{2}=394.400, p<0.001\right.$, d.f. $\left.=8\right)$ and from beach monitoring $\left(X^{2}=235.794, \mathrm{p}<0.001\right.$, d.f.=7).

\begin{tabular}{lcc}
\hline \hline & \multicolumn{2}{c}{ FREQUENCIES OF STRANDED MARINE MAMMALS } \\
SPECIES & DATA FROM NOTIFICATIONS & DATA FROM BEACH MONITORING \\
& $1998-2001$ & $4999-2001^{*}$ \\
\hline \hline Zalophus californianus & 69 & 2 \\
Phoca vitulina richardsi & 7 & 4 \\
Mirounga angustirostris & 2 & 5 \\
Unidentified pinniped & 2 & 1 \\
Delphinus delphis & 4 & 1 \\
Tursiops truncatus & 2 & 0 \\
Lagenorhynchus obliquidens & 1 & 1 \\
Steno bredanensis & 0 & 1 \\
Unidentified odontocete & 0 & 0 \\
Eschrichtius robustus & 2 & 0 \\
Balaenoptera musculus & 1 & 63 \\
\hline TOTAL & 90 & \\
\hline \hline
\end{tabular}

* No data available for 1998, as beach monitoring started in 1999.

\section{Geographic location of strandings}

Marine mammal strandings in Todos Santos Bay were located geographically by species, separated into data from notifications (Figure 2) and from beach monitoring (Figure 3). Both figures show a higher frequency of strandings along the sandy shore (from El Gallo River to Whale's corner) than along the rocky shore (San Miguel Point to El Gallo river).

The data analysis from beach monitoring revealed a significantly higher stranding rate of California sea lions on the sandy shore $(0.3528$ animals $/ \mathrm{km})$ than on the rocky shore $(0.0910$ animals $/ \mathrm{km}$; Mann-Whitney $\mathrm{U}=510.5$, corrected $z=2.46, \mathrm{P}<0.05$, $\left.\mathrm{n}_{1}=42, \mathrm{n}_{2}=36\right)$. Other pinnipeds and cetaceans stranded in much lower numbers than $Z$. californianus, and were distributed randomly along the study area. Therefore, no further analyses were performed.

\section{Strandings by year}

There was a significant difference in the number of strandings per year recorded from notifications, from 1998 to $2001\left(X^{2}=24.933, P<0.001, d f=3\right.$, Table $2)$. There were more strandings in $1998(n=41)-$ almost twice as much as in $1999(n=20)$ and 2000 $(n=21)$ - and five times more than in $2001(n=8)$. Data from beach monitoring (mean stranded marine mammals per $\mathrm{km}$ search effort $=S M M / \mathrm{km}$ ) did not yield significant differences between years 1999-2001 (Table 2).

\section{Strandings by seasons of the year}

There was a significant difference in the number strandings of all species among seasons of the year, recorded from notifications $\left(X^{2}=66.622, P<0.001\right.$, $\mathrm{df}=3$ ). The highest frequency was observed during spring $(n=56)$, followed by winter and summer (both with $n=12)$, and fall $(n=10)$. Data from monitoring also showed significant differences in stranding rates $\left(X^{2}=12.022, \mathrm{P}<0.05, \mathrm{df}=3\right.$, Table 3): $0.3729 \mathrm{SMM} / \mathrm{km}$ in spring, 0.3177 in winter, 0.2740 in summer, and 0.0404 in fall. In addition, during spring we recorded the highest species diversity, and Zalophus californianus was the only species that stranded during all four seasons (Figure 4).

\section{Strandings of California sea lions by age classes and sex}

There was a significant difference in the number of strandings between male and female California sea lions, in both data sets from notifications,1998 to 2001 $\left(X^{2}=3.630, \mathrm{P}<0.05, \mathrm{df}=1\right)$ and from monitoring, 1999$2001\left(X^{2}=16.026, P<0.05, d f=1\right)$, where males stranded more often than females $(63.0 \%$ in notifications, and $82.1 \%$ in monitoring, Table 4). In 1998, however, 55\% were females. In addition, we found a significant difference between age in both data sets (notifications: $X^{2}=27.926, P<0.05, \mathrm{df}=3$; monitoring: $X^{2}=42.128$, $\mathrm{P}<0.05, \mathrm{df}=3$ ), where adults had the highest frequency (50.0\% in notifications and $69.2 \%$ in monitoring, Table 4 ) and pups the lowest ( $0 \%$ and $2.6 \%$, respectively). The exception was again in 1998, when juveniles had the highest frequency (45\%). 
Table 2. Frequencies by year of stranded marine mammals (SMM) in Todos Santos Bay, Baja California, Mexico. Data recorded from notifications (1998-2001) showed significant differences of frequencies between years $\left(X^{2}=24.933\right.$, $p<0.001$, d.f. $\left.=3\right)$, but no differences in data from monitoring $\left(\mathrm{SMM} / \mathrm{km}, X^{2}=3.887, \mathrm{p}>0.05\right.$, d.f. $\left.=2\right)$

\begin{tabular}{lccc}
\hline \hline YEAR & $\begin{array}{c}\text { DATA FROM NOTIFICATIONS } \\
\text { 1998-2001 } \\
\text { SMM }\end{array}$ & $\begin{array}{c}\text { DATA FROM BEACH MONITORING } \\
\text { 1999-2001* }\end{array}$ \\
\hline \hline 1998 & 41 & & \\
1999 & 20 & 23 & 0.3233 \\
2000 & 21 & 21 & 0.2594 \\
2001 & 8 & 19 & 0.2936 \\
\hline \hline TOTAL & 90 & 63 & \\
\hline
\end{tabular}

* No data available for 1998, as beach monitoring started in 1999.

Table 3. Frequencies of stranded marine mammals (SMM) in Todos Santos Bay, Baja California, Mexico, by season of the year. Data recorded from notifications showed significant differences of frequencies between seasons $\left(X^{2}=66.622, p<0.001\right.$, d.f. $\left.=3\right)$, and also from beach monitoring in $\mathrm{SMM} / \mathrm{km}\left(X^{2}=12.022, \mathrm{p}<0.05\right.$, d.f.=3). See text for definition of seasons.

\begin{tabular}{lccc}
\hline \hline SEASON & $\begin{array}{c}\text { DATA FROM NOTIFICATIONS } \\
\text { 1998-2001 } \\
\text { SMM }\end{array}$ & $\begin{array}{c}\text { DATA FROM BEACH MONITORING } \\
\text { 1999-2001* }\end{array}$ \\
\hline Winter & 12 & 22 & 0.3177 \\
Spring & 56 & 29 & 0.3739 \\
Summer & 12 & 9 & 0.2740 \\
Fall & 10 & 3 & 0.0404 \\
\hline \hline TOTAL & 90 & 63 & \\
\hline \hline
\end{tabular}

* No data available for 1998, as beach monitoring started in 1999.

Table 4. Age classes and sex of stranded California sea lions (Zalophus californianus) in Todos Santos Bay, Baja California, Mexico. Data from notifications, 1998-2001 (A); and data from beach monitoring, 1999-2001 (B). Both data sets showed significant differences between age classes and sex. See text for definition of age classes.

\begin{tabular}{|c|c|c|c|c|c|c|}
\hline \multicolumn{7}{|c|}{ A - STRANDED CALIFORNIA SEA LIONS (DATA FROM NOTIFICATIONS, 1998-2001) } \\
\hline & Adults & Subadults & Juveniles & Pups & Total & $\%$ \\
\hline 오 & 10 & 0 & 10 & 0 & 20 & 37.0 \\
\hline$\sigma^{*}$ & 17 & 11 & 6 & 0 & 34 & 63.0 \\
\hline TOTAL & 27 & 11 & 16 & 0 & 54 & $100.0 \%$ \\
\hline$\%$ & 50.0 & 20.4 & 29.6 & 0.0 & $100.0 \%$ & \\
\hline \multicolumn{7}{|c|}{ B - STRANDED CALIFORNIA SEA LIONS (DATA FROM MONITORING, 1999-2001) } \\
\hline & Adults & Subadults & Juveniles & Pups & Total & $\%$ \\
\hline 우 & 5 & 0 & 1 & 1 & 7 & 17.9 \\
\hline$\sigma^{\prime}$ & 22 & 6 & 4 & 0 & 32 & 82.1 \\
\hline TOTAL & 27 & 6 & 5 & 1 & 39 & $100.0 \%$ \\
\hline$\%$ & 69.2 & 15.4 & 12.8 & 2.6 & $100.0 \%$ & \\
\hline
\end{tabular}




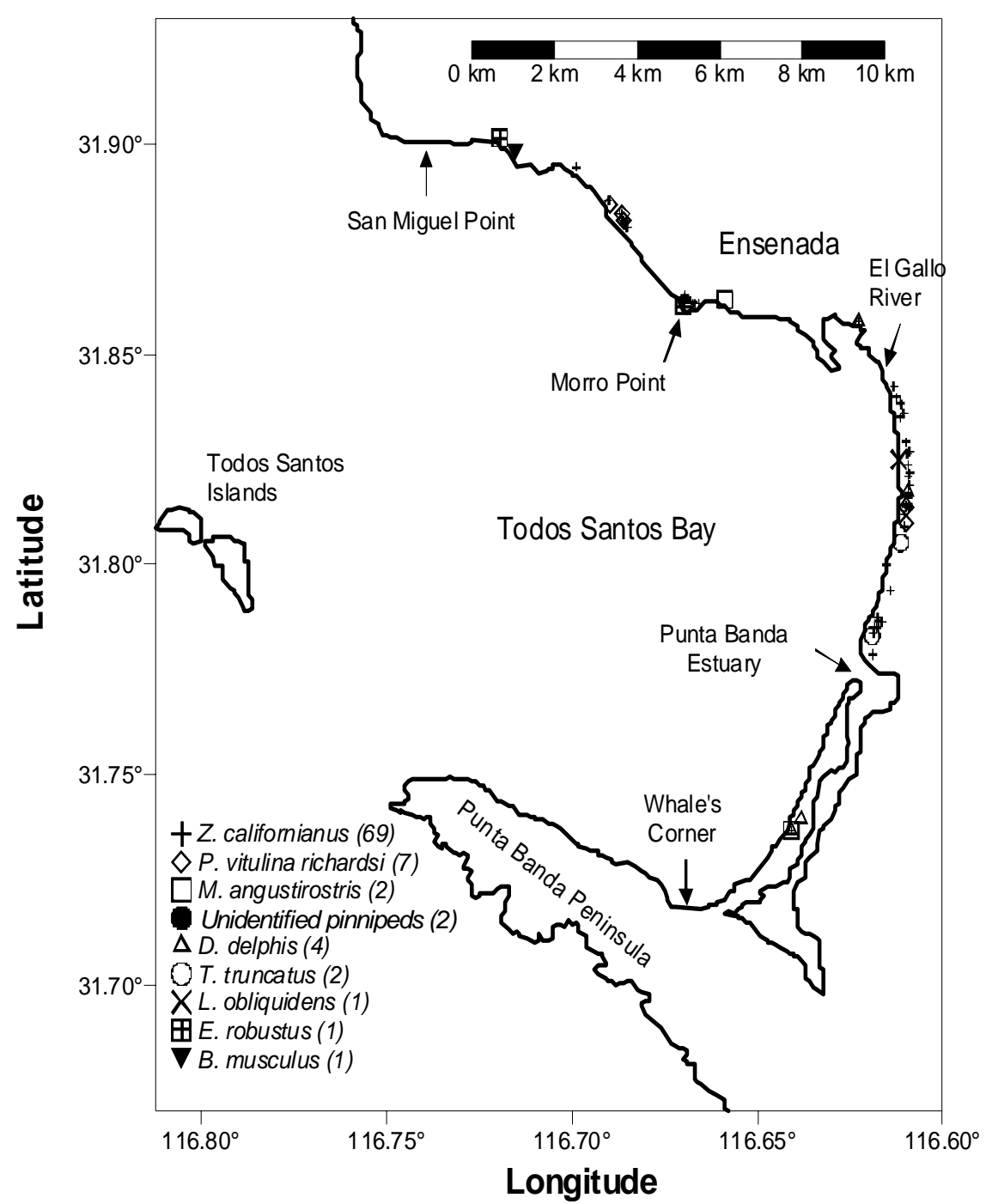

Figure 2. Geographic location of stranded marine mammals in Todos Santos Bay, Baja California, Mexico, 1998 - 2001. Data from notifications.

\section{Possible death causes}

We calculated the rate of stranded marine mammals with wounds indicating possible human-induced injuries. Seventeen percent of all 153 stranded marine mammals ( $\mathrm{n}=26$ : 2 Delphinus delphis and 24 Zalophus californianus) of the animals had wounds caused by bullets, by boat strike or lacerations caused by a cutting object. Both common dolphins were adult females and had broken jaws. One of them was pregnant and had wounds from a boat strike; the other one had injuries caused by a knife. Regarding California sea lions, 18 had bullet wounds and seven had lacerations caused by cutting objects. Moreover, $70 \%$ of these sea lions were males, distributed almost evenly between adults, subadults, and juveniles.

\section{Discussion}

\section{Stranded species}

The stranded species represent $24 \%$ of all 37 species of cetaceans and pinnipeds that occurr along the Baja California Peninsula (Aurioles, 1993; Reeves et al., 2002).The California sea lion is the most frequently stranded species in Todos Santos Bay, coincident with the previous reports for the west coast of the U.S.A. (Seagars and Joswiak, 1991; Wilkinson and Worthy, 1999). For the Baja California Peninsula this may be explained by the higher abundance of Z . californianus compared with other pinnipeds such as harbor and elephant seals (Antonelis and Fiscus, 1980). As for cetaceans, stranding frequencies by species are much lower than for pinnipeds, and relative frequencies of pinnipeds, odontocetes, and mysticetes are comparable to reports from California, USA (Seagars and Joswiak, 1991; Wilkinson and Worthy, 1999).

\section{Geographic location of strandings}

Carcasses of stranded marine mammals were found along the beaches throughout the study area. There are a few differences in location of strandings between 


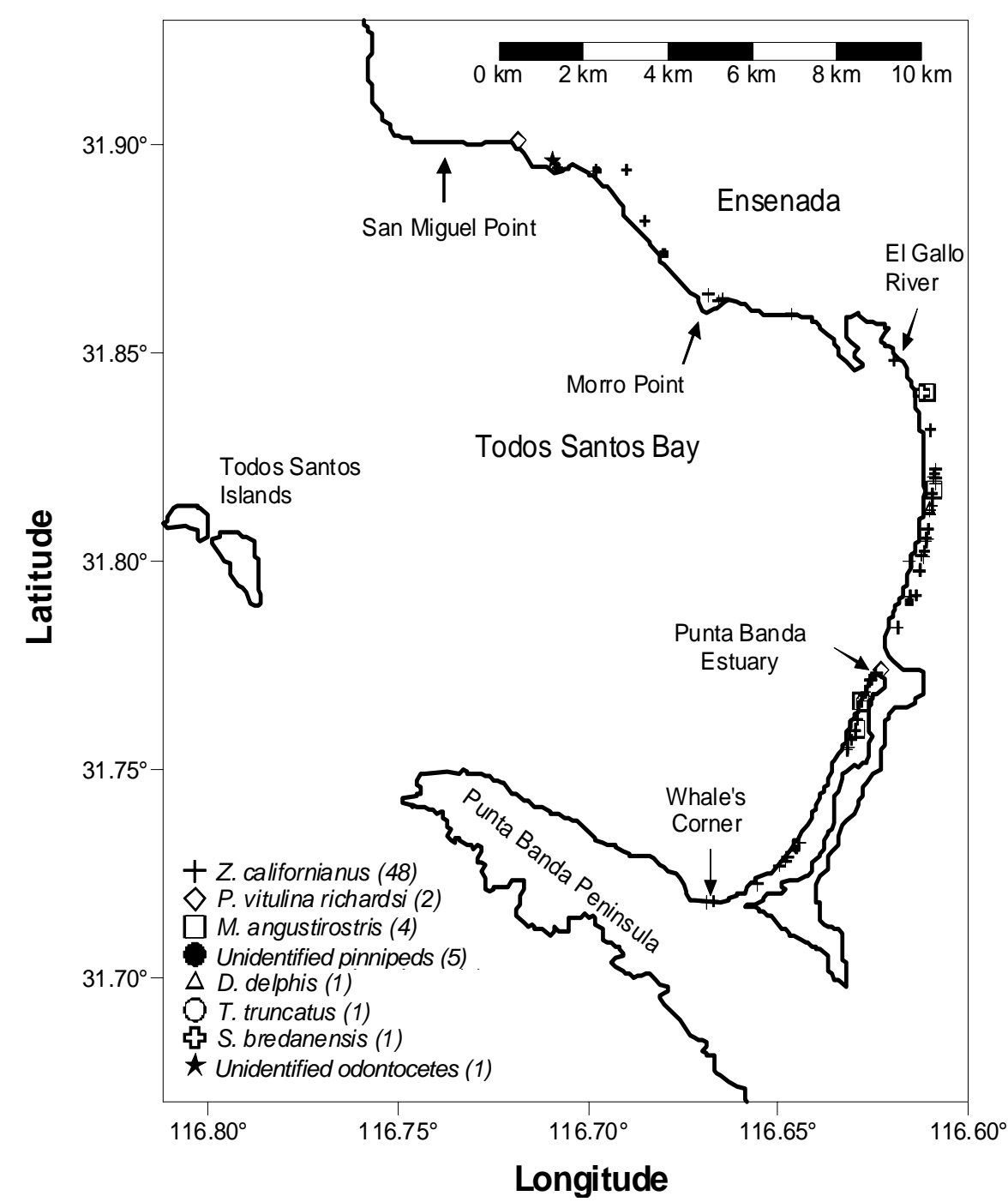

Figure 3. Geographic location of stranded marine mammals in Todos Santos Bay, Baja California, Mexico, 1999 - 2001. Data from beach monitoring.

records from notifications and monitoring (Figures 2 and 3). For example, at Morro point, where the University of Baja California and our stranding group are located, strandings from notifications were more concentrated than from monitoring. In contrast, monitoring yielded more data than notifications on the beaches from the Punta Banda estuary to Whale's corner, a sparsely populated and visited area. The latter difference may be attributed to a more evenly distributed effort during monitoring. We assume, however, that some species that may occur in the area did not strand because the carcasses were transported offshore by ocean currents, sunk before they stranded or were preyed upon by sharks or other scavengers (Duguy, 1978).

However, stranding locations both from notifications and monitoring showed an apparent higher frequency of strandings along the sandy shores than along the rocky shores (Figures 2 and 3). This was confirmed by a statistically significant difference in stranding rate (monitoring data) of California sea lions. This species can be found all over Todos Santos Bay, and the most important colonies are located at Punta Banda Peninsula and from the center to the south of Todos Santos Bay. The higher stranding frequency along the sandy shore compared to the rocky shore is probably due to the fact that animals are more easily deposited there, and this is also explained by a less pronounced slope (less than 30 degrees) than that of the rocky shore. The latter also has steep and small, narrow beaches, and therefore there seems to be little space for carcass deposition during long periods of time (several days or weeks) because they are reached by the high tide and transported again out to sea. Most of the mortality in the study area occurs at sea, where the wind-driven current's direction is almost perpendicular to the sandy shore (Secretaria de Marina, 1974; Argote-Espinoza et al., 1991). Therefore, this factor may contribute to a higher stranding rate along the sandy shore as also noted by Duguy (1978), who found a correlation between strong winds and strandings in his study along the coast of France. 


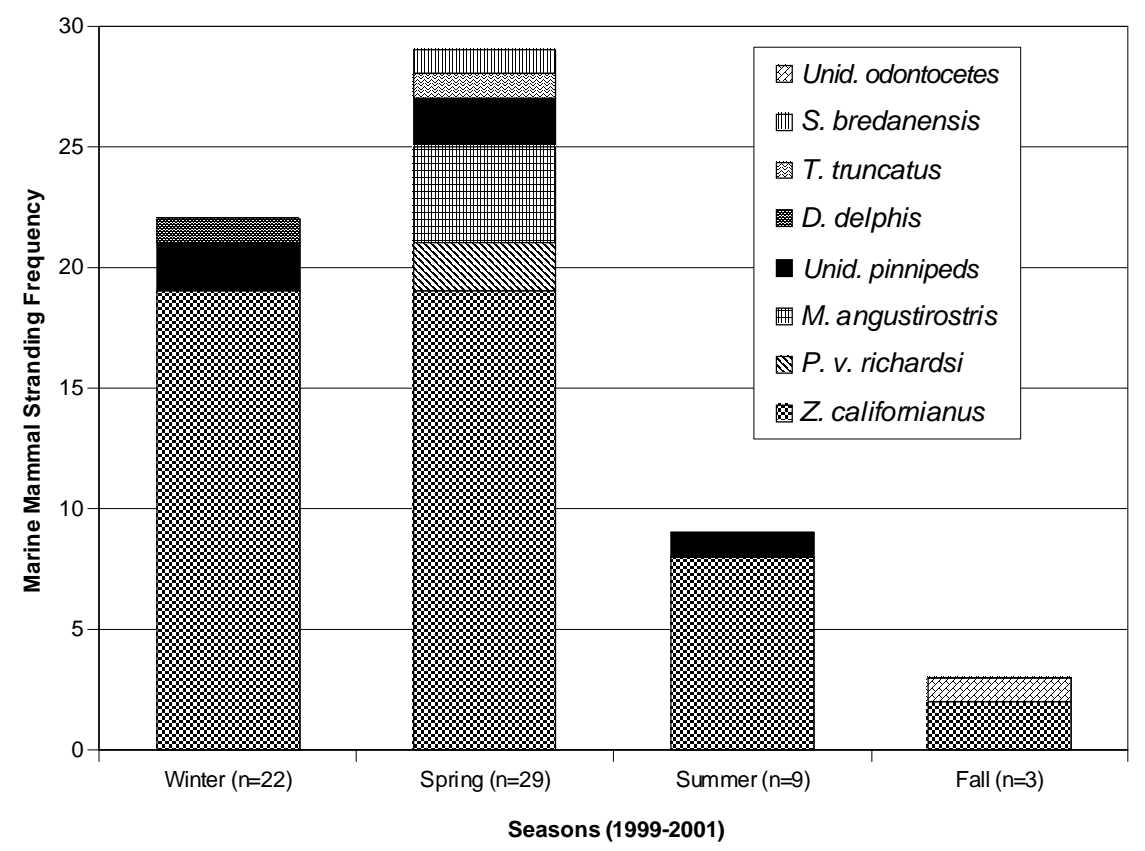

Figure 4. Marine mammal stranding frequencies in Todos Santos, Mexico, for each season (years 1999-2001 combined), recorded from beach monitoring. There was a higher species diversity in spring than in other seasons. See text for definition of seasons.

\section{Strandings by year}

Data from notifications indicated significant differences in stranding frequencies between the years of the study period (1998-2001, Table 2). No differences between years 1999-2001 were detected in beach monitoring data, and this may be due to the lack of data from 1998 (Table 2). In 2001 we recorded more strandings from beach monitoring than from notifications because effort was probably more consistent in the former data set.

Strandings during the year 1998 had the highest frequency, and this represented $45.5 \%$ of all strandings during the four years (data from notifications). Thus, according to Wilkinson's (1996) findings of strandings in California, 1998 may be considered an atypical year of marine mammal mortality. This was probably related to El Niño 1997-1998 that was the strongest during the XX century (McPhaden, 1999; NOAA-CIRES, 2002). During these events, ocean-atmosphere conditions change dramatically. There is a chain reaction of wind and ocean current directions, increase in sea surface temperatures, and a decrease in primary and secondary production. Consequently, there is a reduction in food availability for marine mammals (Idyll, 1973; Barber and Chávez, 1983; Schreiber and Schreiber, 1984).

\section{Strandings by seasons}

During this investigation we observed a statistically significant difference in stranding frequency among seasons, regardless whether the data were recorded from notifications or monitoring (Table 3). Both data sets showed the highest frequency (and stranding rate) in spring and the lowest in fall. However, monitoring data showed a difference in stranding rate between winter and summer in contrast to data from notifications, probably because notifications are related to the presence of people on the beaches.

Winter and spring peaks of pinniped strandings in Baja California are similar to those in California (Seagars and Jozwiak, 1991), and this has been attributed to winter storms and spring winds when large numbers of pinnipeds are overwintering pelagically in California (Seagars and Jozwiak, 1991). As animals may be injured (Keyes, 1965; Le Boeuf et al., 1972), this weakens and exposes them to diseases and attacks by predators (Riedman, 1990). If animals die, strong winds during storms transport the carcasses to shore (Duguy, 1978).

We found the highest marine mammal species diversity during spring, and this pattern coincides with Duguy's (1978) findings, i.e. a higher stranding frequency of cetaceans along the coasts of France occurs during winter and spring. The high frequency of strandings in Todos Santos Bay during winter and spring also may be related to a higher number of species and animals occurring in the area. The harbor seal's breeding season in Todos Santos Bay is from February to May and the elephant seal's from December to March (Riedman, 1990; Reeves et al., 1992; García-Aguilar, 2004). The California sea lion was the most frequently stranded species during all seasons of the year, although the number of stranded animals decreased during summer and fall. This may be explained by the lower abundance at the colonies from May to July (Schramm, unpublished data) because the animals migrate to the rookeries north and south of Todos Santos Bay to breed (Lowry et al., 1992). 


\section{Strandings of California sea lions by age classes and sex}

Age and sex groups of California sea lions (as in other pinniped species) tend to be affected distinctively because of differences in behavior, food-habits and foraging, and habitat type preferences (Geraci et al., 1982; Trillmich and Limberger, 1985; Calzada et al., 1994; Gulland et al., 1996). The Todos Santos Bay colony is composed mainly by adult and subadult males and juveniles of both sexes, with no more that 300 individuals during most part of the year (Schramm, unpublished data). Sea lions in Todos Santos Bay do not reproduce at any time of the year, and therefore adult males do not defend territories to mate nor females gather to give birth. The closest rookeries (reproductive colonies) to Todos Santos Bay are on Los Coronados Islands (De Anda, 1985; Lowry et al., 1992), approximately $100 \mathrm{~km}$ north, and on San Martín Island, approximately $200 \mathrm{~km}$ south (Lowry et al., 1992). Therefore, the higher frequency of stranded males seems to reflect the age and sex structure of the California sea lion colony in Todos Santos Bay.

In addition, we could expect that pups should strand more frequently because they are more sensitive to environmental variables and diseases. At the same time, since this is not a reproductive area, the low percentage of stranded pups may reflect their absence in the area. Moreover, during 1998 we found that $55 \%$ of California sea lions that stranded along Todos Santos Bay were females and $45 \%$ were juveniles. Females may have been more affected than males by the 1997-1998 El Niño because they remain near their reproductive areas yearround (Heath, 2002), and they also forage closer to shore than males (Cárdenas and Aurioles, 20025). In California, during the 1982-1983 El Niño, females stranded in higher numbers than males (Seagars and Jozwiak, 1991). Changes in prey distribution, depth and distance from shore also affect juveniles because they are less capable of reaching their food (Trillmich et al., 1991; Gilmartin and Eberhardt, 1995; Geraci et al., 1999).

An indirect evidence of a decrease in prey abundance for the California sea lion during El Niño 1997-1998 was the low catch of anchovies (Engraulis mordax). During 1998 only 756 tons were captured in Baja California, compared to the annual average of 7803 tons (Anonymous, 2002). This fish is the most important prey of sea lions at Los Coronados Islands, approximately $100 \mathrm{~km}$ north of Todos Santos Bay (De Anda, 1985).

In addition, the highest number of strandings in the USA during the 1990's was recorded during 1998, and approximately $46 \%$ were California sea lions (Le Boeuf, 2000). This coincides with a high sea lion mortality in different places and during different El Niño events (Trillmich and Limberger, 1985; Trillmich et al., 1991; Huber, 1991; Morris et al., 19996).

\section{Possible death causes}

As with the study by Goldstein et al. (1999), Z. californianus was the species that most often presented some kind of human-induced injuries, mainly caused by bullets. This is probably related to the fact that sea lions frequently approach both commercial and sport fishing vessels and take the fish from the lines and the nets (DeMaster et al., 1982; Zavala and Mellink, 1997).

We calculated the rate of age and sex classes involved: $70 \%$ were males, approximately evenly distributed among adults, subadults and juveniles. This figure contrasts with the rates of entangled sea lions in the Gulf of California (Zavala and Mellink, 1997): 41.5\% females, $7.2 \%$ subadult males, $4.8 \%$ adult males and $46.4 \%$ juveniles (sex not determined). This may indicate that males have more interaction with fisheries than females in Todos Santos Bay, possibly because of their variable foraging behavior (Cárdenas and Aurioles, 2002). However, we should also consider that our data may simply reflect the higher abundance of males in our study area. Moreover, we could not determine if trauma was inflicted before or after death, and if the injuries caused the decease of the animals. The experience of stranding recording personnel was variable and only three necropsies were conducted; therefore, the percentage of deaths by human-induced injuries may have been underestimated in this study.

\section{Acknowledgements}

The authors thank the members and volunteers at Investigación y Conservación de Mamíferos Marinos de Ensenada, A. C. (ICMME) for assistance with marine mammal stranding data collection. We also thank Nemer Narchi and Eduardo Morteo for assisting with statistical analysis. Diane Gendron reviewed early drafts of this manuscript. The thorough revisions by the editor and two anonymous referees improved the manuscript considerably. This study was partially funded by Fondo Mexicano para la Conservación de la Naturaleza (FMCN) and Fuerza Editorial. Field work was conducted under permits No. D00.02.-1202 and D.00.02.-1363 from the Mexican National Institute of Ecology.

\footnotetext{
${ }^{5}$ Cárdenas, P.N. and Aurioles, G.D. (2002) Hábitos alimenticios de lobos marinos de California, Zalophus californianus, machos y hembras, en Los Islotes, Bahía de La Paz, Baja California Sur. Page 34 in Abstracts, XXVII Reunión Internacional para el Estudio de los Mamíferos Marinos, SOMEMMA, 12-15 May 2002, Veracruz, Mexico.

${ }^{6}$ Morris, P.A., Oliver, G.W., Elliot, J., Melin, S.R. and DeLong, R.L. (1999) El Niño 1998 and changes in California sea lion, Zalophus californianus, use of Año Nuevo island. Page 131 in Abstracts, XIII Biennial Conference on the Biology of Marine Mammals, 28 November3 December, Maui, Hawaii.
} 


\section{References}

Anonymous (2002) Anuario Estadístico de Pesca 2000. SAGARPA, CONAPESCA, D.F., México.

Antonelis, G.A. JR. AND Fiscus, C.H. (1980) The pinnipeds of the California current. California Cooperative Oceanic Fisheries Investigations Reports 21:68-78.

Argote-Espinoza, M.L., Gavidia-Medina, F.J. and AmadorBuenrostro. A. (1991) Wind-induced circulation in Todos Santos bay, Baja California, México. Atmosfera 4: 101-115.

Aurioles, G.D. (1993) Biodiversidad y estado actual de los mamíferos marinos en México. Revista de la Sociedad Mexicana de Historia Natural 44: 397-412.

Barber, R.T. AND ChÁvez, F.P. (1983) Biological consequences of El Niño. Science 222: 1203-1210.

Calzada, N., Lockyer, C.H. and Aguilar, A. (1994) Age and sex composition of the striped dolphin die-off in the western Mediterranean. Marine Mammal Science 10: 299-310.

Carwardine, M. (2000) Whales, Dolphins and Porpoises. Dorling Kindersley Inc., London, United Kingdom.

De Anda, M.H. (1985) Hábitos alimenticios del lobo marino Zalophus californianus en las Islas Los Coronados, Baja California, México. B Sc thesis. Facultad de Ciencias Marinas, Universidad Autónoma de Baja California. Ensenada, Baja California, Mexico.

DeMaster, D.P., Miller, D.J., Goodman, D., DeLong, R.L. And STEWART, B.S. (1982) Assessment of California sea lion and fishery interactions. Transactions of the North American Wildlife and Natural Resources Conference 47: 253-264.

DuguY, R. (1978) Researches on the mortality factors of cetaceans on the coasts of France. Aquatic Mammals 6(1): 9-13.

García-Aguilar, M.C. (2004) Breeding biology of the northern elephant seal (Mirounga angustirostris) at the Isla San Benito del Oeste, Eastern Pacific, México. Aquatic Mammals 30(2): 289-295.

García, P.L. And Chee, B.G. (1976) Ecología de la zona de entremareas de la Bahía de Todos Santos. Ciencias Marinas 3(1): 10-29.

Geraci, J.R. And Lounsbury, V.J. (1993) Marine Mammals Ashore: A Field Guide for Strandings. Texas A \& M Sea Grant College Program, Galveston, Texas, USA.

Geraci, J.R., St. Aubin, D.J., Barker, I.K., Webster, R.G., Hinshaw, V.S., Bean, W.J., Ruhnke, H.L., Prescott, J.H., EARLy, G., BAKER, A.S., Madoff, S. AND SChOOLEY, R.T. (1982) Mass mortality of harbor seals: Pneumonia associated with influenza A virus. Science 215: 1129-1131.

Geraci, J.R., Harwood, J. And Lounsbury, V.J. (1999) Marine mammal die-offs. Causes, investigation and issues. Pages 367-395 in Twiss JR., J.R. AND REEves, R.R. (Eds) Conservation and Management of Marine Mammals. Smithsonian Institution Press, Washington, DC, USA.

Goldstein, T., Johnson, S.P., Phillips, A.V., Hanni, K.D., Fauduier, D.A. AND Gulland, F.M.D. (1999) Human-related injuries observed in live stranded pinnipeds along the central California coast 1986-1998. Aquatic Mammals 25(1): 43-51.

Gulland, F.M.D., Koski, M., Lowenstine, L.J., Colagross, A., Morgan, L. ANd Spraker, L. (1996) Leptospirosis in California sea lion (Zalophus californianus) stranded along the central California coast, 1981-1994. Journal of Wildlife Diseases 32(4): 572-580.

Hare, M.P. And MeAd, J.G. (1987) Handbook for determination of adverse human-marine mammal interactions from necropsies. National Marine Fisheries Service, Northwest and Alaska Fisheries Center Processed Report 87-06.
Heath, C.B. (2002) California, Galapagos, and Japanese sea lions (Zalophus californianus, Z. wollebaeki, and Z. japonicus). Pages 180-186 in Perrin, W.F., WÜRsIG, B. AND Thewissen, J.G.M. (Eds) Encyclopedia of Marine Mammals. Academic Press, San Diego, California, USA.

Huber, H.R. (1991) Changes in the distribution of California sea lions north of the breeding rookeries during the 1982-83 El Niño. Pages 129-137 in Trillmich, F. AND ONO, K.A. (Eds) Pinnipeds and El Niño. Responses to Environmental Stress. Springer-Verlag. Ecological Studies, Vol. 88, Berlin, Germany.

IDYLL, C.P. (1973) The anchovy crisis. Scientific American 228: $22-29$.

Kennedy-Stoskopf, S. (2001) Viral diseases. Pages 285-307 in Dierauf, L.A. AND GulLAND, F.M.D. (Eds) CRC Handbook of Marine Mammal Medicine. Second Edition. CRC Press, Boca Raton, Florida, USA.

KeYes, M.C. (1965) Pathology of the northern fur seal. Journal of the American Veterinary Medical Association 147:1090-1095.

KING, J.E. (1983) Seals of the World. British Museum (Natural History). Comstock Publishing Associates, Ithaca, New York, USA.

Le Boevf, B.J., Whiting, R.J. and Gantt, R.F. (1972) Perinatal behavior of northern elephant seal females and their young. Behaviour 43:121-156.

Le Boeuf, B.J., Aurioles, D., Condit, R., Fox, C. , Gisiner, R., Romero, R. AND Sinsel, F. (1983) Size and distribution of the California sea lion population in Mexico. Proceedings of the California Academy of Sciences 43(7): 77-85.

Le Boeuf, N.R. (2000) Marine Mammal Protection Act of 1972 Annual Report: January 1, 1998 to December 31, 1998. U.S. Department of Commerce, NOAA, NMFS, Office of Protected Resources. 101 pp.

Lowry, M.S., Boveng, P., DeLong, R.J., Oliver, C.W., Stewart, B.S., De Anda, H. and Barlow, J. (1992) Status of the California sea lion (Zalophus californianus californianus) population in 1992. Administrative Report LJ-92-32. National Marine Fisheries Service, Southwest Fisheries Center, La Jolla, California. 24 pp.

Lynn, R.M., Dierauf, L.A. And Gulland, F.M.D. (2001) Marine mammals as sentinels of ocean health. Pages 3-13 in Dierauf, L.A. AND Gulland, F.M.D. (Eds) CRC Handbook of Marine Mammal Medicine. Second edition. CRC Press, Boca Raton, Florida, USA.

McPhaden, M.J. (1999) Genesis and evolution of the 1997-98 El Niño. Science 283: 950-954.

MeAD, J.G. (1979) An analysis of cetacean strandings along the eastern coast of the United States. Pages 54-68 in Geraci, J.R. And St. Aubin, D.J. (Eds) Biology of Marine Mammals: Insight Through Strandings. Report No. MMC77/13. Marine Mammal Comission.

Neave, H.R. and Worthington, P.L. (1988) Distribution-Free Tests. Unwin Hyman Ltd, London, United Kingdom.

NOAA-CIRES. 2002. Multivariate ENSO Index (MEI). http:/ / www.cdc.noaa.gov/ kew/MEI/

ReAD, A.J. AND Murray, J.T. (2000) Gross Evidence of Human-Induced Mortality in Small Cetaceans. NOAA Technical Memorandum NMFS-OPR-15. U.S. Department of Commerce, National Oceanic and Atmospheric Administration, National Marine Fisheries Service.

ReEves, R.R., Stewart, B.S. AND Leatherwood, S. (1992) The Sierra Club Handbook of Seals and Sirenians. Sierra Club Books, San Francisco, California, USA.

Reeves, R.R., Stewart, B.S., Clapham, P.J. and Powell, J.A. (2002) National Audubon Society Guide to Marine Mammals of the World. Chanticleer Press, New York, New York, USA. 
Riedman, M. (1990) The Pinnipeds: Seals, Sea Lions, and Walruses. University of California Press, Berkeley, California, USA.

Rowles, T.K., Van Dolah, F.M. and Hohn, A.A. (2001) Gross necropsy and specimen collection protocols. Pages 449470 in Dierauf, L. and Gulland, F.M.D. (Eds) CRC Handbook of Marine Mammal Medicine. Second Edition. CRC Press LLC, Boca Raton, Florida, USA.

SChreiber, R.W. AND Schreiber, E.A. (1984) Pacific seabirds and the El Niño Southern Oscillation: 1982 to 1983 perspectives. Science 225: 713-716.

Seagars, D.J. And Jozwiak, E.A. (1991) The California marine mammal stranding network, 1972-1987: implementation, status, recent events, and goals. Pages 25-33 in Reynolds III, J.E. ANd Odell, D.K. (Eds) Marine Mammal Strandings in the United States. Proceedings of the Second Marine Mammal Stranding Workshop Miami, Florida, December 3-5, 1987. NOAA Technical Report NMFS 98. National Marine Fisheries Services, Silver Spring, Maryland, USA.

SeCRETARía de Marina (1974) Estudio geográfico de la región de Ensenada, Baja California. Dirección General de Oceanografía y Señalamiento Marítimo, D.F., México.

SHESKIN, D.J. (2000) Handbook of Parametric and Nonparametric Statistical Procedures. Chapman and Hall/CRC Press, Boca Raton, Florida, USA.

Ккосн, E.J. (1990) Heavy metals in marine mammals: Presence and analytical methods. Pages 127-138 in Dierauf, L. (Ed.) CRC Handbook of Marine Mammal Medicine: Health, Disease and Rehabilitation. CRC Press, Boca Raton, Florida, USA.

Torres, R. and ZÁrate, S. (1991) Costa occidental de Baja California. Oceanografía Física. Pages 267-296 in DE LA Lanza, G. (Ed.) Oceanografía de Mares Mexicanos. AGT Press, D.F. Mexico.

Trillmich, F. and Limberger, D. (1985) Drastic effects of El Niño on Galapagos pinnipeds. Oecologia 67(1):19-22.
Trillmich, F., Ono, K.A., Costa, D.P., DeLong, R.L., FeldKamp, S.D., Francis, J.M., Gentry, R.L., Heath, C.B., Le Boeuf, B.J., Majluf, P. AND YoRK, A.E. (1991) The effects of El Niño on pinniped populations in the Eastern Pacific. Pages 247270 in Trillmich, F. And ONo, K.A. (Eds) Pinnipeds and El Niño. Responses to Environmental Stress. Springer-Verlag, Ecological Studies, Vol. 88. Berlin, Germany.

U.S. Naval Observatory (2002). Earth's Seasons Equinoxes, Solstices, Perihelion, and Aphelion 1992-2020. http:// aa.usno.navy.mil/data/docs/EarthSeasons.html

Wiley, D.N., Asmutis, R.A., Pitchford, T.D. And GAnNon, D.P. (1995) Stranding and mortality of humpback whales, Megaptera novaeangliae, in the mid-Atlantic and southeast United States, 1985-1992. Fishery Bulletin 93(1): 196-205

WiLKINSON, D.M. (1996) National contingency plan for response to unusual marine mammal mortality events. Technical Memorandum NMFS-OPR-9. National Oceanographic and Atmosferic Administration, U.S. Department of Commerce. Wilkinson, D. AND Worthy, G.A.J. (1999) Marine mammal stranding networks. Pages 396-411 in TwISS JR., J.R. AND ReEves, R.R. (Eds) Conservation and Management of Marine Mammals. Smithsonian Institution Press, Washington, DC, USA.

WoodHouse, C.D. (1991) Marine mammal beachings, indicators of population events. Pages 111-116 in ReYNOLDS III, J.E. AND ODELL, D.K. (Eds) Marine Mammal Strandings in the United States. Proceedings of the Second Marine Mammal Stranding Workshop; Miami FL; December 3-5, 1987. U.S. Department of Commerce, NOAA Technical Report NMFS 98.

ZAR, J.H. (1996) Biostatistical Analysis. Third Edition. Prentice Hall, New Jersey, USA.

Zavala-GonZÁlez, A. AND MellinK, E. (1997) Entanglement of California sea lions, Zalophus californianus, in fishing gear in the central-northern part of the Gulf of California, Mexico. Fishery Bulletin 95: 180-184. 